\title{
Ovule ontogenesis and megasporogenesis in Adesmia latifolia (Spreng.) Vog. (Leguminosae-Papilionoideae) $^{1}$
}

\author{
MARIA C.C. $\mathrm{MOÇO}^{2,3}$ and JORGE E.A. MARIATH ${ }^{2}$
}

(received: January 29, 2003; accepted: September 11, 2003)

\begin{abstract}
Ovule ontogenesis and megasporogenesis in Adesmia latifolia (Spreng.) Vog. (Leguminosae-Papilionoideae)). The ovule ontogenesis and the megasporogenesis events were studied under bright field, fluorescence and scanning electron microscopy. The primordium is 3-zonate and gives rise to a hemianatropous, bitegmic and crassinucellate ovule. The archesporium may consist of one or more archesporial cells, but only one undergoes meiosis, forming a linear tetrad. Normally, only a single megaspore is functional in the chalazal position, but occasionally two functional chalazal megaspores arise. The present study provides additional information on embryological characters in the Adesmieae tribe and discusses their taxonomic significance to the Leguminosae family.
\end{abstract}

Key words - Adesmia, embryology, Leguminosae, megaspore, ovule

RESUMO - (Ontogênese do óvulo e megasporogênese em Adesmia latifolia (Spreng.) Vog. (Leguminosae - Papilionoideae)). A ontogênese do óvulo e os eventos da megasporogênese foram estudados sob microscopia de campo claro, fluorescência e eletrônica de varredura. O primórdio é trizonado e origina um óvulo hemianátropo, bitegumentado e crassinucelado. O arquespório pode ser composto de mais de uma célula arquesporial, mas apenas uma sofre meiose formando uma tétrade linear. Normalmente, apenas um megásporo é funcional na posição calazal, mas foram registrados alguns casos em que os dois megásporos calazais eram, simultâneamente, funcionais. O presente estudo acrescenta informações sobre caracteres embriológicos na tribo Adesmieae e discute sua importância taxonômica na família Leguminosae.

Palavras-chave - Adesmia, embriologia, Leguminosae, megásporo, óvulo

\section{Introduction}

The tribe Adesmieae is monogeneric and endemic to southern South America (Chile, Bolivia, Peru, Argentina, Uruguay and Brazil) and includes 230 species (Burkart 1967). In Brazil there are 17 species, one of them with two varieties, limited to the Rio Grande do Sul, Paraná and Santa Catarina States (Miotto \& Leitão Filho 1993). Several analyses have been performed to elucidate the phylogenetic relationship of this tribe within the Papilionoideae (Polhill 1981, Polhill et al. 1981, Chappill 1995, Doyle et al. 1997, Lavin et al. 2001). However, despite the usefulness of the embryological characters in this type of analysis, few studies have been made on the Adesmia species. Citations only exist regarding the absence of crystals in the anther tapetum of Adesmia muricata (Jacq.) DC. and A. tenella Hook.

\footnotetext{
1. Parte da Tese de Doutorado de M.C.C. Moço, Universidade Federal do Rio Grande do Sul.

2. Universidade Federal do Rio Grande do Sul, Departamento de Botânica, Laboratório de Anatomia Vegetal, Av. Bento Gonçalves 9500, Prédio 43423, sala 206, 91501-970 Porto Alegre, RS, Brasil. jorge.mariath@ufrgs.br

3. Autor para correspondência: chiaramoco@yahoo.com.br
}

\& Arn. (Buss \& Lersten 1972) and for seed development in A. securigerifolia Hert. (Izaguirre et al. 1994).

Morphological characters of the ovules and details of megasporogenesis have been widely used in systematic studies. Bocquet (1959) and Bocquet \& Bersier (1960) were the first to stress the importance of the ovule ontogenesis. Bouman (1971, 1974, 1984) proposed hypotheses based on the ontogenesis of the ovules and their integuments about angiosperms phylogeny. Other studies have used ovule characters to investigate phylogeny, particularly in the families Rubiaceae (Andronova 1977, Galati 1991, Mariath \& Cocucci 1997) and Loranthaceae (Cocucci \& Venturelli 1982).

Rembert (1966, 1969a, b, 1971) used the marked variability in the great megaspore tetrads to make phylogenetic hypotheses in Leguminosae. Other characters are taxonomically important for the family, such as: ovule type, number of archesporial cells, number of parietal layers and the alignment pattern of the integuments (Davis 1966, Prakash 1987, Johri et al. 1992).

The objective of this study was to analyse the development of the ovule and the megasporogenesis events in Adesmia latifolia (Spreng.) Vog. 


\section{Material and methods}

Floral buds of Adesmia latifolia (Spreng.) Vogel were collected from cultivated plants at the Agronomic Station of the Federal University of Rio Grande do Sul in the Eldorado do Sul city, RS. A voucher specimen was placed in ICN Herbarium (ICN 122710), Botany Department at the same university.

The pistils were fixed in glutaraldehyde $1 \%$ and formaldehyde 4\% (McDowell \& Trump 1976), in sodium phosphate buffer $0.1 \mathrm{M}, \mathrm{pH} 7.2$; dehydrated in ethanol and included in hydroxyethylmethacrylate (Gerrits \& Smid 1983). The blocks were sectioned at 1.5-2 $\mu \mathrm{m}$ with a Zeiss Mikron microtome. The sections were stained with Toluidine Blue $\mathrm{O}$ $0.05 \%, \mathrm{pH} 4.4$ (Feder \& O'Brien 1968) for observation under bright field optical microscopy. Callose was identified by the reaction with Aniline Blue (Martin 1959), using a UV 340-380 nm filter (Dichromirror $400 \mathrm{~nm}$ ) under fluorescence microscopy. The observations and photomicrographs were made with a Leica DMR-HC microscope.

For scanning electron microscopy, the material was fixed in FAA (5:5:90 v/v) (Johansen 1940), dehydrated in ethanol and dimethoxymethane (Gersterberger \& Leins 1978), dried at critical point and metalized with gold using a sputtering system. The observations and electronmicrographs were made with a JEOL 5800 at $20 \mathrm{kV}$.

\section{Results}

The carpel is already closed when the first ovule primordium appears (figure 1). Ovule initiation is basipetal and starts with mitotic activity in meristematic regions organized in three layers: dermal, subdermal and central (figure 2).

The initial archesporial cell is distinguished from the other subdermal cells, because it presents a larger volume, dense cytoplasm and distinct nucleolus (figure 3). This cell divides and gives rise, outerly to the primary parietal cell and, innerly to the archesporial cell proper (figure 4). The primary parietal cell undergoes periclinal, anticlinal and /or oblique divisions, contributing to form two or three nucellar parietal layers (figures 5, 6). In a few cases more than one initial archesporial cell was recorded, constituting a multicellular archesporium (figures 6,7). Simultaneously with the division of the initial archesporial cells, other subdermal cells also undergo periclinal divisions and increase the mass of nucellar cells.

The two integuments are initiated from periclinal and oblique divisions of dermal cells (figure 8). The outer integument develops asymmetrically, rising from distal primordium flank. The inner one differentiates simultaneously as a ring around the nucellus (figure 9).
The ovules are disposed alternately along the carpel suture (figure 9).

The archesporial cell proper grows and diferenciate directly to a megaspore mother cell which compresses the lateral cells and becomes elongated on the nucellar major axis (figure 10). Meiosis I forms equally-sized dyad cells (figure 11). Meiosis II is asynchronous, since the chalazal dyad cell divides before the micropylar one (figure 13). The resulting tetrad is linear and the two micropylar megaspores are ephemerous (figure 14). Callose was detected only in the transverse wall of the dyad and between the three chalazal megaspores (figures 12, 15). Normally, the chalazal megaspore is the functional one (figures 16,17), but in some cases it was observed that the epichalazal one does not degenerate and remains functional.

The differentiation of the outer integument, in the proximal flank of the primordium occurs later and determines a Y-shaped micropyle aperture (figures 18, 19). Further asymmetrical ovule growth creates the anatropous curvature. The outer integument superimposes the inner one forming a hemianatropous ovule with a zig-zag micropylar channel (figure 20). The inner integument has two cell layers, while the outer one 3-4 layers in the basal and median region, and up to 8-10 layers in the micropylar region (figure 20).

\section{Discussion}

Bouman (1974, 1984) compared cellular organization in the ovule primordium with the shoot apical meristem. According Bouman's classification, Adesmia latifolia (Spreng.) Vogel is tri-zonate. There are no similar studies in legume species and further comparative investigations may be useful to elucidate phylogenetic relationships among the subfamilies.

The ovule of Adesmia latifolia is hemianatropous as a result of the anatropous ontogeny, according to the ontogenetic classification of Bocquet \& Bersier (1960). This anatropous curvature, as in other legumes, is usually related to unequal growth at funiculus region (Bocquet 1959, Bocquet \& Bersier 1960, Bor 1978, Bouman \& Boesewinkel 1991). Some authors classified this type of ovule as campylotropous (Reeves 1930, Pal 1960, Rembert 1967, Ojeaga \& Sanyaolu 1970, Oomman 1971, Deshpande \& Bhasin 1976) or anacampylotropous (Prakash \& Chan 1960). Such controversy is certainly due the outer integument growth, displacing the exostome to near the hilum and forming a zig-zag micropylar channel. 
Other aspects are also considered important for the typology of the ovules in angiosperms, such as origin and sequence of integument formation (Bouman 1971, 1974, 1984). Bouman (1974) cited the Papilionoideae as characterized by an outer integument with subdermal derivation, but in Arachis (cf. the drawings of Smith 1956), Melilotus (Cooper 1933), and now Adesmia latifolia, the integuments are both from dermal origin.

The sequence of the inner vs. outer integument initiation in the Leguminosae is extremely variable. In

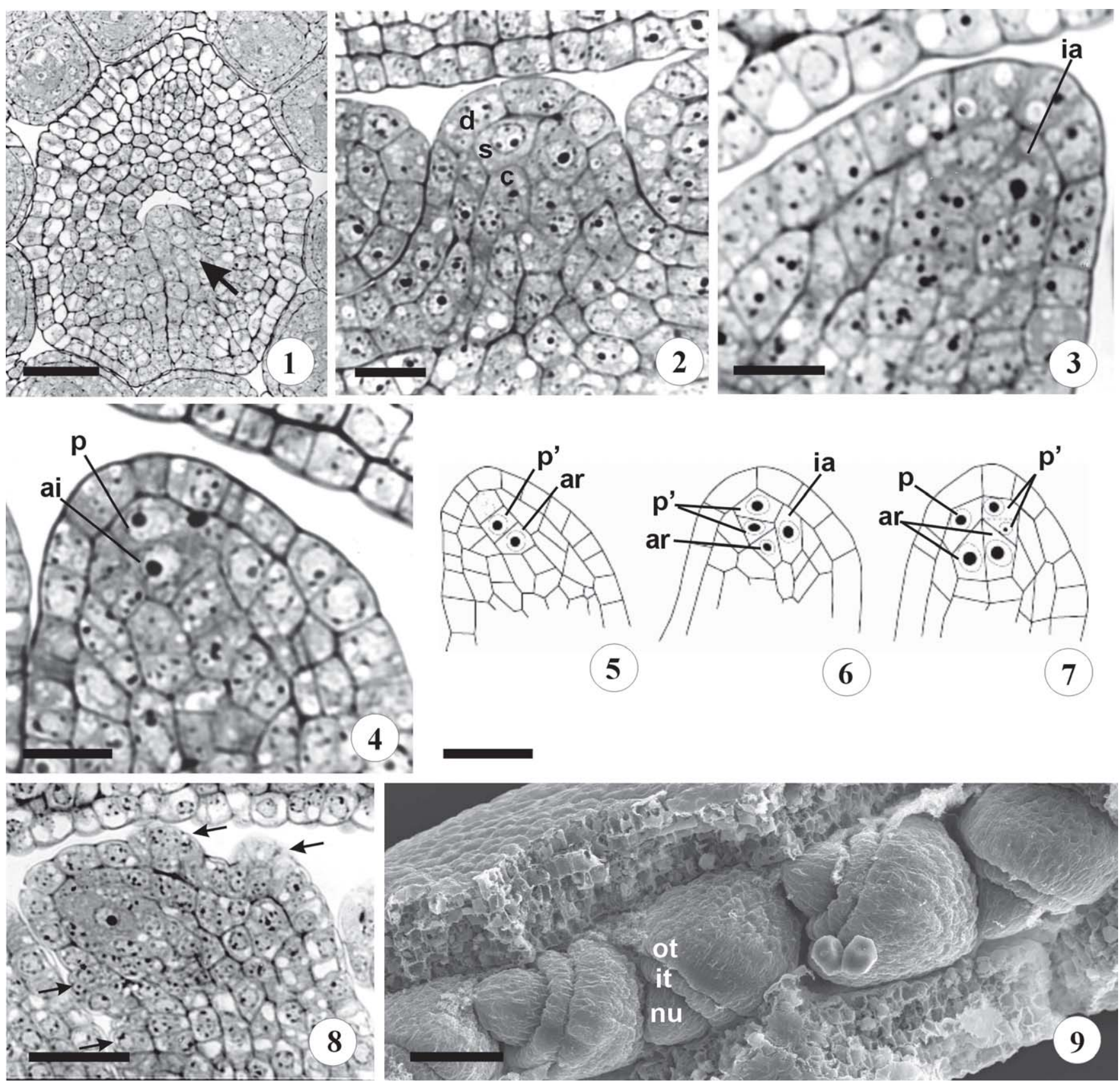

Figures 1-9. Photomicrography of longitudinal section of the carpel in 1 and transversal in 2,3,4 and 8. Schematic drawings from 5 to 7 . Electronmicrographies in scanning electron microscopy in 9. 1. Ovule primordium initiation. 2. Primordium with 3-zonate organization. 3. Initial archesporial cell in subdermal position. 4. Primary parietal cell and archesporial cell proper. 5. Periclinal division of the primary parietal cell. 6. Oblique division of the primary parietal cell. 7. Formation of two archesporial cells. 8. Dermal origin of the integuments (arrows). 9. Alternate disposition of the ovules within the carpel. Integument formation. $(\mathrm{ar}=$ archesporial cell proper; $\mathrm{c}=$ central layer; $\mathrm{d}=$ dermal layer; $\mathrm{ia}=$ initial archesporial cell; it $=$ inner integument; $\mathrm{nu}=$ nucellus; ot $=$ outer integument; $\mathrm{p}=$ primary parietal cell; $\mathrm{p}^{\prime}=$ derived parietal cell; $\mathrm{s}=$ subdermal layer $)$. Scale bar $=50 \mu \mathrm{m}(1,9), 10 \mu \mathrm{m}(2)$, $20 \mu \mathrm{m}(3,4,8), 40 \mu \mathrm{m}(5-7)$. 
some taxa the inner integument develops first (Cooper 1933, Roy 1933, Pantulu 1945, Dnyansagar 1954, Smith 1956, Dnyansagar 1957, Rembert 1967, Lim \& Prakash 1994). However, in Medicago sativa L., Vicia americana Muhl., Trifolium pratense L., T. hybridum L., T. repens L. (Martin 1914), Cajanus and Lathyrus
(Roy 1933), Tamarindus (Paul 1937), Glycine (Rembert 1977) and in Adesmia latifolia, the first to develop is the outer one.

Other characters of the ovules are important, particularly for the Leguminosae family, such as the number of cell layers in each integument and the
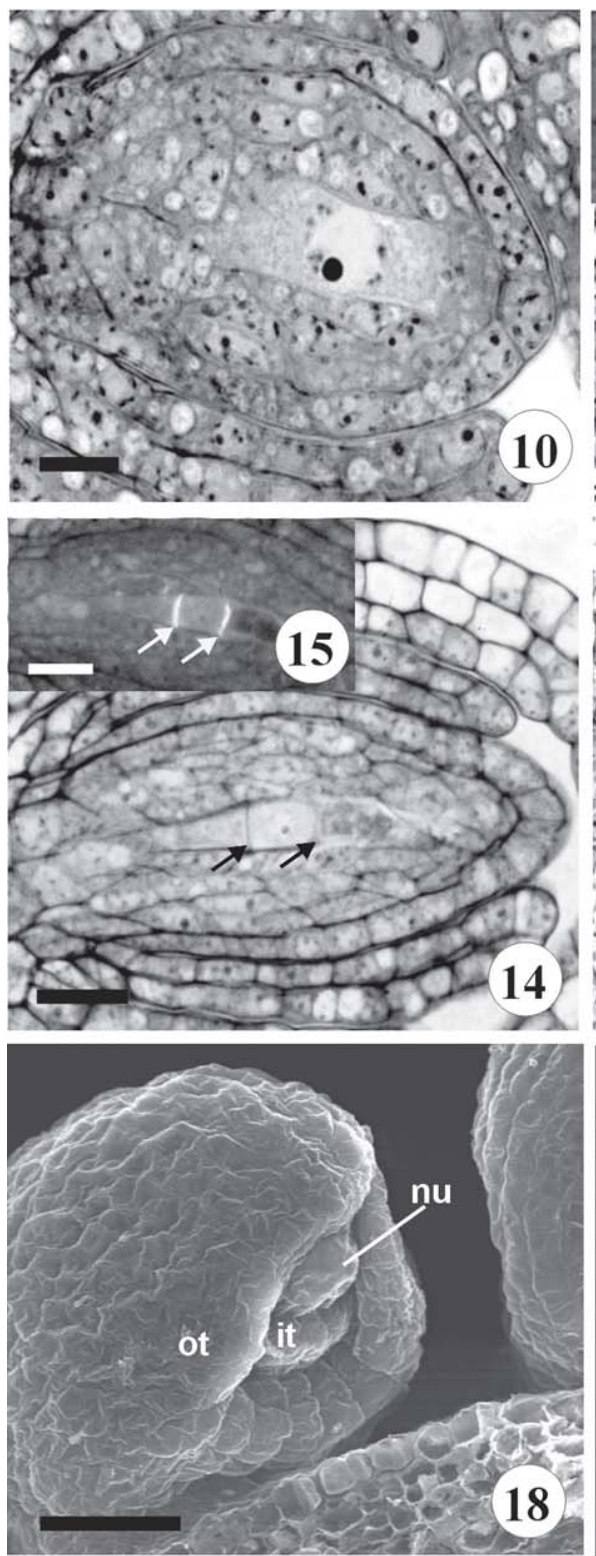
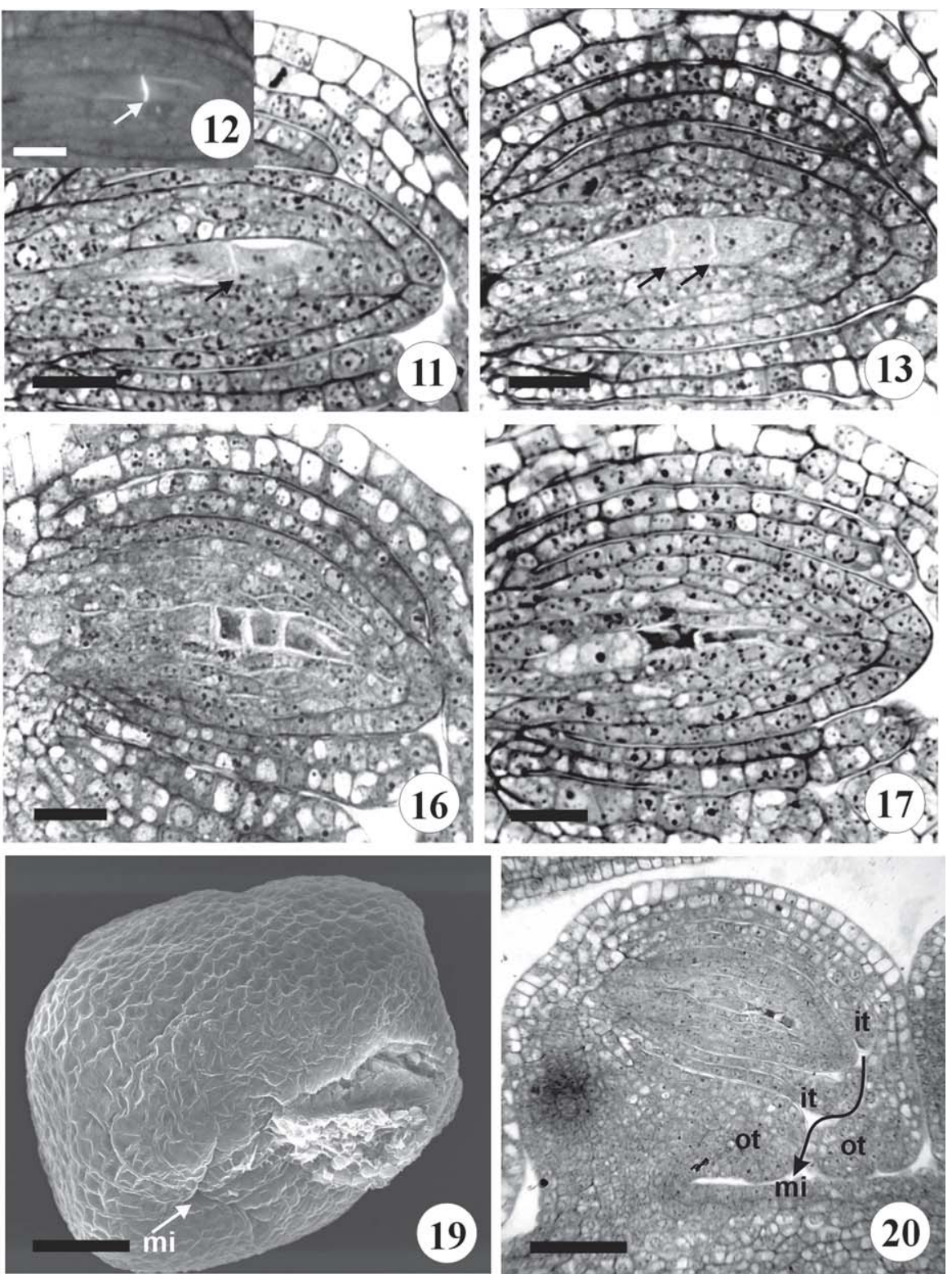

Figures 10-20. Photomicrographies of longitudinal section of the carpel from 10 to 17 and 20. Fluorescence microscopy in 12 and 15. Electromicrographies in scanning electron microscopy in 18 and 19. 10. Mother cell of megaspores. 11. Dyad cells. 12. Detail of the transversal wall of the dyad with callose (arrows). 13. Newly-formed linear tetrad, arrows indicating cell walls. 14. Tetrad with two degenerating micropylar megaspores, arrows indicating cell walls. 15. Detail of transversal walls of the tetrad with callose (arrows). 16. Tetrad with three degenerating micropylar megaspores. 17. Functional chalazal megaspore when vacuolation begins. 18. Growth of the integuments over the nucellus. 19. Y-shaped micropyle aperture (arrow). 20. hemianatropous ovule with a zig-zag micropyle channel (arrow). (it = inner integument; $\mathrm{mi}=$ micropyle aperture; nu = nucellus; ot = outer integument). Scale bar $=10 \mu \mathrm{m}(10-17), 20 \mu \mathrm{m}(20), 50 \mu \mathrm{m}(18,19)$. 
participation of integuments in micropyle formation. The inner integument in Adesmia latifolia, as in most Leguminosae, consists of two cell layers (Cooper 1933, Roy 1933, Samal 1936, Paul 1937, Smith 1956, Dnyansagar 1957, Hindmarsh 1964, Deshpande \& Bhasin 1974, Rembert 1977, Ashrafunnisa \& Pullaiah 1994, 1999). However, in Glycine javanica L., Tephrosia, Clitoria ternata L., Pongamia glabra Vent. (Anantaswamy Rau 1951), Teramnus labialis (L.f.) Spreng. (Anantaswamy Rau 1953), Psophocarpus tetragonolobus (L.) DC. (Lim \& Prakash 1994) and also in species of Cassia (Pantulu 1945) it is formed by more than two layers. An outer integument with several cell layers, as in the ovules of Adesmia latifolia, is also common in Leguminosae, except for a few Mimosoideae (Dnyansagar 1954) and Glycine max L. (Prakash \& Chan 1976) in which the outer integument, has only two layers. Recently, studies on the genetic and molecular control of ovule development, have concluded that the two integuments have an independent origin from an evolutionary standpoint (Angenent \& Colombo 1996, Schneitz et al. 1998). This could explain the great variability found in the structure of these layers.

The nucellus of the Leguminosae ovules is crassinucellate (Prakash 1987), which was also found in Adesmia latifolia. This type has been considered to be the plesiomorphic condition in angiosperms (Sporne 1969). The definitions of nucellus types, however, do not take into account some aspects which Rutishauser (1982) considered to be important in the evolution of the archesporium, such as the origin of its cells and the moment when the vegetative potential is converted to a reproductive one, as previously emphasized by Warming (1878). The crucial point in Rutishauser's work (1982) was the demonstration that the archesporium is composed only of cells that will undergo meiosis. In many studies on megasporogenesis in Leguminosae species, erroneous interpretations were made about archesporial cells, differentiated into sub-hypodermal or variable position (Roy 1933, Samal 1936, Rembert 1969a, b, Prakash 1987). Probably, this misinterpretation of the archesporial cell position is due to the difficulty in distinguishing the initial archesporial cell during the early stages of development.

Comparative studies of megasporogenesis in the Leguminosae have shown great variability in tetrad types, which prompted the phylogenetic analyses of Rembert (1966, 1969a, b, 1971). This author described the occurrence of twelve types of tetrads and the supposed evolutionary lines within the family, having as a basal type a linear tetrad with a functional chalazal megaspore. The linear tetrad, as found in Adesmia latifolia and in most legumes, was considered by Rembert a basic type. Variations in the position of the functional megaspore have been reported in Trifolium repens (Martin 1914) and Vicia faba L. (Mitchell 1975) with an epichalazal position, and in Milletia ovalifolia Kurz (Pal 1960), where it may be in a chalazal, micropylar or epichalazal position. A tetrad with more than one functional megaspore, as found in Adesmia latifolia, is not commonly recorded in the Leguminosae family. Chalazal and micropylar megaspore have been described in Trifolium hybridum (Kazimierski \& Kasimierski 1979), and in some australian species of the tribe Mirbelieae (Cameron \& Prakash 1994). Hindmarsh (1964) recorded vacuolation in all four megaspores of the tetrad in Trifolium pratense, but only the chalazal one became larger, while the others degenerated. In Cassia abbreviata Oliv. the chalazal megaspore is functional but the epichalazal one persists for a while and is the last one to degenerate (Rembert 1969a, 1971). An extreme case was described by Cameron \& Prakash (1994), in which the archesporium is multicellular, producing several tetrads, and each of which may present up to four functional megaspores.

Many authors indicated that callose deposition during the megasporogenesis is the main factor which identifies the functional megaspore. Rodkiewicz (1970) noted that callose appears at the beginning of the meiotic prophase and then it remains in the transverse walls and in the pole of the non-functional megaspore. The justification for this process is that callose probably diminishes the permeability of the megaspores cell wall, causing nutrient flow reduction. Kennell \& Horner (1985) initially identified the presence of callose in chalazal region of the megaspore mother cell and then in the transversal wall of the tetrad, in Glycine max. However, it has been demonstrated that other cytological processes influence megaspore fate, such as organelle polarization and presence of plasmodesmata interconnecting the functional megaspore to the neighboring nucellar cells (Willemse 1981, Willemse \& Boer-De 1981, Raghavan 1997). In Adesmia latifolia callose was not found in the wall of the megaspore mother cell, but was observed only in the transversal walls of the dyad and tetrad, indicating that other factors may influence the fate of the megaspores in this species.

The present study is the first to discuss ontogenetic characters of the ovule and megasporogenesis in the tribe Adesmieae. Several characters of potential taxonomic significance for this tribe were observed, such as the trizonate ovule primordium, a 
hemianatropous ovule type, dermal origin of the integuments, asymmetrical initiation of the outer integument and linear tetrad with the presence of one or two functional megaspores.

Acknowledgements - We would like to thank CNPq for doctorate studentship and research grants for $1^{\text {st }}$ and $2^{\text {nd }}$ authors, respectively, and the FAPERGS for their financial support; the director and technicians of the Electron Microscopy Center at the Federal University of Rio Grande do Sul (CME/UFRGS) for the use of equipment; the employees in the Agronomic Station of UFRGS for their help during field collection; Bibiana Cassol for technical support in the Plant Anatomy Laboratory, Department of Botany/UFRGS; and Profa. Hedy Hofmann and Dr. Peter Gibbs for the english version and text review, respectively.

\section{References}

ANANTASWAMY RAU, M. 1951. The endosperm in some of the Papilionaceae. Phytomorphology 1:153-158.

ANANTASWAMY RAU, M. 1953. Some observations on the endosperm in Papilionaceae. Phytomorphology 3:209-222.

ANDRONOVA, 1977. On the structure of the ovule of Rubiaceae. Botanische Zeitung 62:1461-1469.

ANGENENT, G.C. \& COLOMBO, L. 1996. Molecular control of ovule development. Trends in Plant Science 1:228-232.

ASHRAFUNNISA \& PULLAIAH, T. 1994. Embryology of Galactia (Fabaceae). Phytomorphology 44:253-260.

ASHRAFUNNISA \& PULLAIAH, T. 1999. Embryology of Teramnus labialis (Fabaceae). Phytomorphology 49:192-202.

BOCQUET, G. 1959. The campylotropous ovule. Phytomorphology 9:223-227.

BOCQUET, G. \& BERSIER, J.D. 1960. La valeur systématique de l'ovule: développements tératalogiques. Archives des Sciences 13:475-496.

BOR, J. 1978. A note on anatropy versus orthotropy. Phytomorphology 28:219-224.

BOUMAN, F. 1971. The application of tegumentary studies to taxonomic and phylogenetic problems. Berichte der Deutschen Botanischen Gesellschaft 84:169-177.

BOUMAN, F. 1974. Developmental studies of the ovule integuments and seed in some angiosperms. PhD thesis, University of Amsterdam, Naarden.

BOUMAN, F. 1984. The ovule. In Embryology of Angiosperms (B.M. Johri, ed.). Springer-Verlag, Berlin, p.123-157.

BOUMAN, F. \& BOESEWINKEL, F.D. 1991. The campylotropous ovules and seed, their structure and functions. Botanische Jahrbücher für Systematik 113:255-270.

BURKART, A. 1967. Leguminosae. In Flora de la Provincia de Buenos Ayres (A. Cabrera, ed.). v.4, pars 3, p.464-484.
BUSS JUNIOR, P.A. \& LERSTEN, N.R. 1972. Crystals in tapetal cells of the Leguminosae. Botanical Journal of the Linnean Society 65:81-85.

CAMERON, B. \& PRAKASH, N. 1994. Variations of the megagametophyte in the Papilionoideae. In Advances in Legume Systematics 6: Structural Botany (I.K. Ferguson \& S. Tucker, eds.). Royal Botanic Gardens, Kew, p.97-115.

CHAPPILL, J.A. 1995. Cladistic analysis of the Leguminosae: the development of an explicit phylogenetic hypothesis. In Advances in Legume Systematics 7: Phylogeny (M. Crisp \& J. Doyle, eds.). Royal Botanic Gardens, Kew, p.1-9.

COCUCCI, A.E. \& VENTURELLI, M. 1982. El ovulo e gineceu en Loranthaceae. Boletin de la Sociedad Argentina de Botanica 21:131-141.

COOPER, D.C. 1933. Macrosporogenesis and embryology of Mellilotus. Botanical Gazette 95:143-155.

DAVIS, O.L. 1966. Systematic embryology of the Angiosperms. John Wiley \& Sons, New York.

DESHPANDE, P.K. \& BHASIN, R.K. 1974. Embryological studies in Phaseolus aconitiifolius Jacq. Botanical Gazette 135:104-113.

DESHPANDE, P.K. \& BHASIN, R.K. 1976. A contribution to the life history of Zornia diphylla Pers. Journal of Indian Botanical Society 55:115-124.

DNYANSAGAR, V.R. 1954. Embryological studies in the Leguminosae. VI. Inflorescence, sporogenesis, and gametophytes of Dichrostachys cinerea W. \& A. and Parkia biglandulosa W. \& A. Lloydia 17:263-274.

DNYANSAGAR, V.R. 1957. Embryological studies in the Leguminosae. V. Prosopis spicigera and Desmanthus virgatus. Botanical Gazette 118:180-186.

DOYLE, J.J., DOYLE, J.L., BALLENGER, J.A., DICKSON,E.E., KAJITA, T. \& OHASHI, H. 1997. A phylogeny of the chloroplast gene rbcL in the Leguminosae: taxonomic correlations and insights into the evolution of nodulation. American Journal of Botany 84:541-554.

FEDER, N. \& O'BRIEN, T.P. 1968. Plant microthechnique: some principles and new methods. American Journal of Botany 55:123-142.

GALATI, G.G. 1991. Estúdios embriológicos en la tribo Spermacoceae (Rubiaceae). Parte I: Anatomia Floral. Megásporogénesis. Megagametogénesis. Boletin de la Sociedad Argentina de Botánica 27:7-20.

GERRITS, P.O. \& SMID, L. 1983. A new, lesstoxic polymerization system for the embedding of soft tissues in glycol methacrylate and subsequent preparing of serial sections. Journal of Microscopy 132:81-85.

GERSTERBERGER， P. \& LEINS， P. 1978. Rasterelektronenmikroskopische Untersuchungen an Blutenknospen von Physalis philadelphica (Solanaceae) Anwendung einer neuen Präparationsmethode. Berichte der deutschen Botanischen Gesellschaft 91:381-387. 
HINDMARSH, G.J. 1964. Gametophyte development in Trifolium pratense L. Australian Journal of Botany 12:1-14.

IZAGUIRRE, S.M., MÉROLA, S. \& BEYHAUT, R. 1994. Seed ontogeny in Adesmia securigerifolia (FabaceaeAdesmieae). Nordic Journal of Botany 14:547-556.

JOHANSEN, D.A. 1940. Plant Microtechnique. McGraw-Hill, New York.

JOHRI, B.M., AMBEGAOKAR, K.B. \& SRIVASTAVA, P.S. 1992. Comparative embryology of Angiosperms. v. 1. Springer-Verlag, New York.

KAZIMIERSKI, T. \& KAZIMIERSKI, E.M. 1979. Structure of embryo sac, fertilization and development of embryo in Swedish clover (Trifolium hybridum L.) plants with reduced leaves. Acta Societatis Botanicorum Poloniae 48:365-375.

KENNELL, J. \& HORNER, H.T. 1985. Megasporogenesis and megagametogenesis in soybean, Glycine max. American Journal of Botany 72:1553-1564.

LAVIN, M., PENNINGTON, T., KLITGARD, B.B., SPRENT, J.I., LIMA, H.C. \& GASSON, P.E. 2001. The dalbergioid legumes (Fabaceae): delimitation of a pantropical monophyletic clade. American Journal of Botany 88:503-533.

LIM, A.L. \& PRAKASH, N. 1994. Embryology and seed development in the winged bean, Psophocarpus tetragonolobus. Gardens' Bulletin 46:79-92.

MARIATH, J.E.A. \& COCUCCI, A.E. 1997. The ovules of Relbunium hypocarpium in the context of the Rubiaceae. Kurtziana 25:141-150.

MARTIN, J.N. 1914. Comparative morphology of some Leguminosae. Botanical Gazette 58:154-167.

MARTIN, F.W. 1959. Staining and observering pollen tubes in the style by means of fluorescence. Stain Technology 34:125-128.

MCDOWELL, E.M. \& TRUMP, B. 1976. Histological fixatives for diagnostic light and eletron microscopy. Archieves of Pathology \& Laboratory Medicine 100:405-414.

MIOTTO, S.T.S. \& LEITÃO FILHO, H.F. 1993. Leguminosae - Faboideae, Gênero Adesmia DC. In Flora Ilustrada do Rio Grande do Sul. Boletim do Instituto Biociências, Universidade Federal do Rio Grande do Sul, Porto Alegre, v.52, p.1-157.

MITCHELL, J.P. 1975. Megasporogenesis and microsporogenesis in Vicia faba. Canadian Journal of Botany 53:2804-2812.

OJEAGA, O. \& SANYAOLU, M.O. 1970. Ovule formation and embryo development in persisting and abortive fruits of the cowpea Vigna unguiculata. Nigerian Journal of Science 4:31-40.

OOMMAN, C.I. 1971. Studies in the Papilionaceae. 2. Gametophytes of Rhyncosia capitata D.C. (R. aurea D.C.). Botanique 2:145-150.
PANTULU, J.V. 1945. Studies in the Caesalpinioideae. I. A contribution to the embryology of the genus Cassia. Jornal of Indian Botanical Society 24:10-24.

PAL, N. 1960. Development of the seed of Milletia ovalifolia. Botanical Gazette 122:130-137.

PAUL, A.K. 1937. Development of ovule and embryo sac of Tamarindus indica L. Journal of Indian Botanical Society 16:151-157.

POLHILL, R.M. 1981. Papilionoideae. In Advances in Legume Systematics 1 (R.M. Polhill \& P.H. Raven, eds.). Royal Botanic Gardens, Kew, p.191-208.

POLHILL, R.M., RAVEN, P.H. \& STIRTON, C.H. 1981. Evolution and systematics of the Leguminosae. In Advances in Legume Systematics 1 (R.M. Polhill \& P.H. Raven, eds.). Royal Botanic Gardens, Kew, p.1-26.

PRAKASH, N. 1987. Embryology of the Leguminosae. In Advances in Legume Systematics 3 (C.H. Stirton, ed.). Royal Botanic Gardens, Kew, p.241-278.

PRAKASH, N. \& CHAN, Y.Y. 1976. Embryology of Glycine max. Phytomorphology 26:302-309.

RAGHAVAN, V. 1997. Molecular embryology of flowering plants. Cambridge University Press, Cambridge.

REEVES, R.G. 1930. Development of the ovule and embryo sac of alfalfa. American Journal of Botany 17:239-246.

REMBERT JUNIOR, D.H. 1966. Megasporogenesis in Laburnum anagyroides Medic. - a case of bisporic development in Leguminosae. Transactions Kentucky Academy of Science 27:47-50.

REMBERT JUNIOR, D.H. 1967. Development of the ovule and megagametophyte in Wisteria sinensis. Botanical Gazette128:223-229.

REMBERT JUNIOR, D.H. 1969a. Comparative megasporogenesis in Caesalpiniaceae. Botanical Gazette 130:47-52.

REMBERT JUNIOR, D.H. 1969b. Comparative megasporogenesis in Papilionaceae. American Journal of Botany 56:584-591.

REMBERT JUNIOR, D.H. 1971. Phylogenetic significance of megaspore tetrad patterns in Leguminales. Phytomorphology 21:317-416.

REMBERT JUNIOR, D.H. 1977. Contribution to ovule ontogeny in Glycine max. Phytomorphology 27:368-370.

RODKIEWICZ, B. 1970. Callose in cell walls during megasporogenesis in Angiosperms. Planta 93:39-47.

ROY, B. 1933. Studies in the development of the female gametophyte in some leguminous crop plants of India. Indian Journal of Agricultural Science 3:1098-1107.

RUTISHAUSER, A. 1982. Introducción a la embriología y biologia de la reproducción de las angiospermas. Editorial Hemisferio Sur, Buenos Aires.

SAMAL, K.K. 1936. The development of the embryo sac and embryo in Crotalaria juncea. Journal of Indian Botanical Society 15:19-31. 
SCHNEITZ, K., BALASUBRAMANIAN, S. \& SCHIEFTHALER, U. 1998. Organogenesis in plant: the molecular and genetic control of ovule development. Trends in Plant Science 3:468-472.

SMITH, B.W. 1956. Arachis hypogea: normal megasporogenesis and syngamia with occasional single fertilization. American Journal of Botany 43:81-89.

SPORNE, K.R. 1969. The ovule as an indicator of evolutionary status in angiosperms. New Phytolologist 68:555-566.
WARMING, E. 1878. De l'ovule. Annales des Sciences Naturelles - Botanique et Biologie Vegetale sér. 6:177-266.

WILlEMSE, M.T.M. 1981. Polarity during megasporogenesis and megagametogenesis. Phytomorphology 31:124-134.

WILLEMSE, M.T.M. \& BOER-DE, J.D. 1981. Megasporogenesis and early megagametogenesis. Acta Societatis Botanicorum Poloniae 50:111-120. 